\title{
Pluriannual evolution of the hydrochemistry of two Alpine lakes (Lake Paione Inferiore and Lake Paione Superiore, Ossola Valley) in relation to atmospheric loads
}

\author{
Rosario MOSELLO*, Aldo MARCHETTO, Angela BOGGERO, Maria Cristina BRIZZIO, Gabriele A. TARTARI and \\ Michela ROGORA
}

C.N.R. Istituto Italiano di Idrobiologia, L.go V. Tonolli 50, 28922 Verbania Pallanza, Italy

*e-mail corresponding author: r.mosello@iii.to.cnr.it

\begin{abstract}
Lakes Paione Inferiore and Paione Superiore (LPI, LPS) are extremely sensitive to acidification, so they are useful as indicators in studying changes in atmospheric pollutant fluxes on waterbodies. Regular trends observed in the last 3-4 years cannot merely be a consequence of seasonal or interannual variations. Increasing $p H$ and alkalinity are mainly driven by a decrease in acidic inputs from the atmosphere, which have been halved over the last 10 years. This trend of atmospheric deposition chemistry has emerged in several sampling stations in the subalpine and Alpine area, in the watershed of Lake Maggiore. The decrease in deposition acidity is mainly related to a decrease in sulphate, while nitrate and ammonium deposition is still high, resulting in high nitrate concentrations in lake waters.
\end{abstract}

Key words: mountain lakes, Alps, acidification, chemistry, trend

\section{INTRODUCTION}

Studies on surface water acidification performed in the second half of the seventies revealed a high level of acidity in atmospheric deposition over the Lake Maggiore area (Mosello \& Tartari 1982; Mosello \& Marchetto 1995). These results gave rise to a series of studies aimed at showing the geographical extent of this problem and its impact on surface water. The effects turned out to be significant only for a small number of Alpine lakes, thanks to the favourable geo-lithological characteristics of catchments that almost completely neutralise atmospheric acidity (Boggero et al. 1993; Mosello et al. 1993b). As a consequence, research focused on high altitude lakes characterised by small catchments, sometimes made up of rocks like granites and gneiss, which are unable to neutralise atmospheric acidity. After extensive studies, we chose two acid-sensitive lakes to enable us to study weathering processes and to evaluate trends. The lakes chosen were Paione Superiore (LPS) and Paione Inferiore (LPI), located in the Bognanco Valley (Ossola Valley, Central Alps). Available chemical data on these lakes go back approximately twenty years (Mosello et al. 1992; Marchetto et al. 1995); they were also studied in detail in the forties and fifties (Tonolli 1947, 1949).

Over the last ten years the Paione lakes have been studied in the framework of projects financed by the European Union: "Quantification of the susceptibility of Alpine lakes to acidification" (1988-1991), "AL:PE, Acidification of mountain Lakes: Palaeolimnology and Ecology" (1991-1994) and "MOLAR: MOuntain LAkes Research". These researches focused attention on high altitude environments, which are considered good indicators of the effects of atmospheric pollution on a regional scale, and of climatic change. The lakes do not suffer from any other anthropogenic disturbances, such as local pollution or change in land use (Wathne et al. 1995; Patrick et al. 1998).

The ongoing MOLAR project studies 34 lakes throughout Europe and is based on the co-operation of 22 laboratories from 12 different countries. The main objectives of the project are: (1) to measure the dynamic response of remote mountain lakes to acidification, (2) to quantify and model pollutant fluxes and pathways and their uptake by fish, (3) to measure and model the temporal response of arctic and remote lacustrine ecosystems to climate variability.

This paper considers the results of chemical analyses on the Paione lakes since 1984, particularly seasonal variations, in relation to snowmelt, atmospheric deposition and algal activity, and the long term trend of the main chemical variables, compared with those of atmospheric deposition. A description of the area of the lakes and a overview of recent studies on them are reported in Mosello et al. (1992).

\section{STUDY AREA}

Lakes Paione Superiore and Inferiore are located in the Bognanco Valley, a lateral of the Ossola Valley, in the Central Alps (Pennine and Lepontine) in Piedmont (Italy) (Fig. 1). The Bognanco Valley surface is 91.8 $\mathrm{km}^{2}$; it has a W-E orientation and a marked asymmetry between the northern and southern parts. The River Bogna flows through it for about $15 \mathrm{~km}$. LPI and LPS are located respectively at 2002 and $2269 \mathrm{~m}$ a.s.l. They 


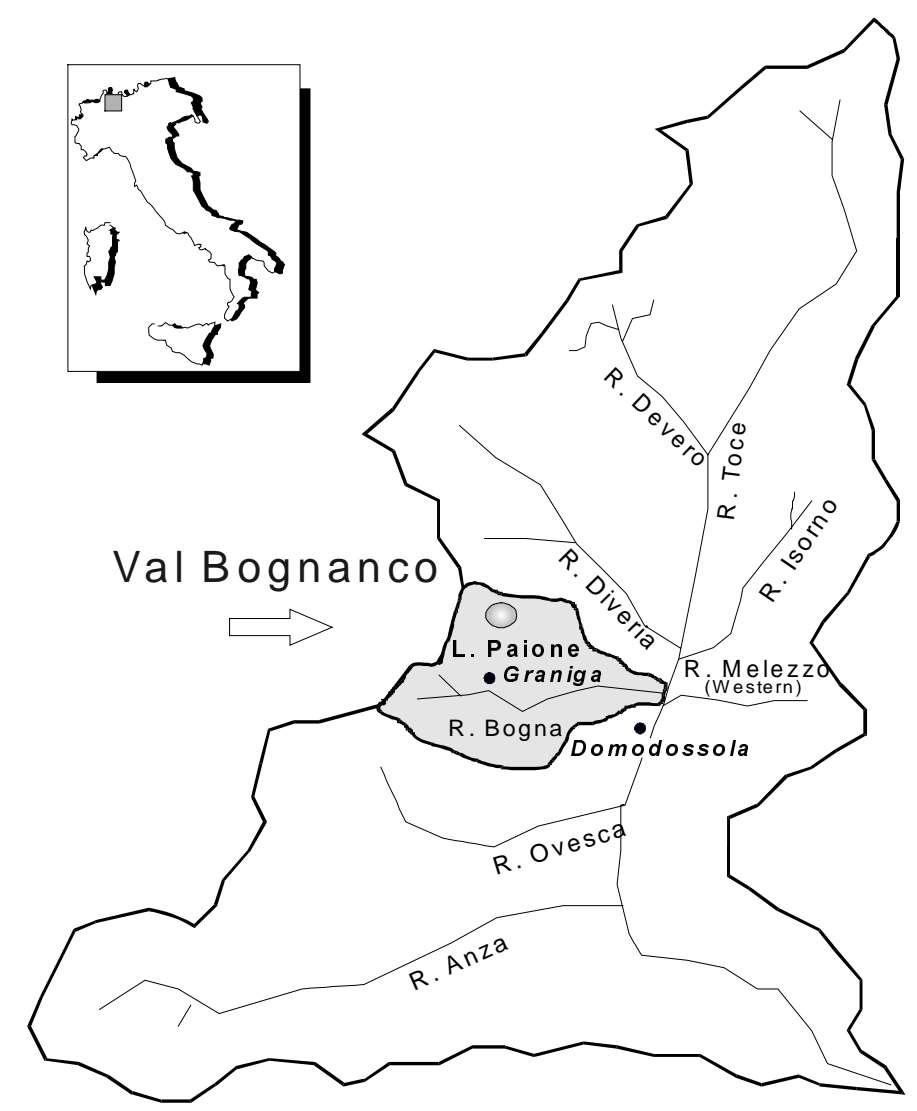

Fig.1. Location of the Paione lakes and of the sampling sites of atmospheric deposition (Domodossola and Graniga) in Ossola Valley.

Tab. 1. Main geographical and hydrological characteristics of Paione lakes.

\begin{tabular}{lccc}
\hline & & L. Paione Inferiore & L. Paione Superiore \\
\hline Altitude & $\mathrm{m}$ a.s.l. & 2002 & 2269 \\
Latitude & North & $46^{\circ} 10^{\prime} 14^{\prime \prime}$ & $46^{\circ} 11^{\prime} 39^{\prime \prime}$ \\
Longitude & East & $08^{\circ} 11^{\prime} 26^{\prime \prime}$ & $08^{\circ} 11^{\prime} 26^{\prime \prime}$ \\
Lake surface area & $\mathrm{km}^{2}$ & 0.0068 & 0.0086 \\
Watershed area (lake included) & $\mathrm{km}^{2}$ & 1.26 & 0.50 \\
(Watershed + lake)/lake ratio & & 184.63 & 57.71 \\
Maximum depth & $\mathrm{m}$ & 13.5 & 11.7 \\
Mean depth & $\mathrm{m}$ & 7.4 & 5.1 \\
Lake volume & $10^{6} \mathrm{~m}^{3}$ & 0.05 & 0.04 \\
Mean residence time & days & 23 & 33 \\
\hline
\end{tabular}

are glacial lakes and form part of a system consisting altogether of three lacustrine environments. Their watersheds are not affected by any anthropogenic disturbance or soil use. From a geo-lithological point of view, most of the catchment is made up of clear banded orthogneiss and grey gneiss. The land cover is mainly alpine meadow, which is restricted to small areas, most of the watershed surface being characterised by bare rocks and debris. The main geographical and hydrological characteristics of the watersheds of the Paione lakes are presented in table 1. The pluviometric and deposition sampling station of Graniga is located in the Bognanco Valley, at $1113 \mathrm{~m}$ a.s.l., about $5 \mathrm{~km}$ from the Paione lakes; Domodossola is at the mouth of the same valley, at $270 \mathrm{~m}$ a.s.l. (Fig. 1).

\section{SAMPLING AND METHODS}

Water samples from the Paione lakes for chemical analysis were collected near the deepest point, at the end of summer and, from 1984 to 1988, during the snowmelt; from 1991 sampling became more frequent and was performed also in winter. Sampling depths were 0 or $1,2.5,5$ and $8 \mathrm{~m}$ for LPS and $0,2.5,5$ and $10 \mathrm{~m}$ for LPI. The following variables were analysed: $\mathrm{pH}$, conductivity, alkalinity (acidimetric titration), main anions (sulphate, nitrate and chloride) by ion chromatography, main cations (calcium, magnesium, sodium and potassium) by atomic adsorption and, from 1991, by ion chromatography; ammonium, reactive silica and reactive and total phosphorus by spectrophotometry (indo- 
phenol-blue and ammonium molibdate with ascorbic acid, respectively). As no stable thermal stratification was detected in the lakes, from the samples collected at various depths we calculated a mean value using a weighted average based on the water volume at different depths.

From January 1994 atmospheric depositions were sampled every week at Graniga using a wet-only collector (Fig. 1). In this paper the measured concentrations are compared with those of Domodossola, for which data have been available since 1986 .

Trends of atmospheric deposition and lake water chemistry were considered for the period 1984-1998. Analytical methods were carefully evaluated to assure the comparability of the data, in spite of some changes in analytical methods which were introduced during the period (Tartari \& Mosello 1997). According to this comparison, we decided not to take into account data collected on the Paione lakes prior to 1984, when ion chromatography was introduced for anion analysis (Tartari \& Mosello 1997).

\section{RESULTS}

Atmospheric deposition chemistry and the amounts of precipitation collected at Graniga and Domodossola are reported in table 2. For both sampling sites, data are available only for the period 1994-1998. Volumeweighted mean values reveal a slightly greater amount of precipitation for Graniga, while there are only small differences between the two stations in the values of the main chemical variables. On the whole, depositions are slightly acidic ( $\mathrm{pH}$ 4.67-4.68), with hydrogen ion, ammonium and calcium as the most important cations, and sulphate and nitrate dominant among the anions. The concentrations of sodium, magnesium and chloride are considerably lower, as might be expected considering the great distance of these sites from the sea. Bicarbon- ate concentrations, corresponding to the values of total alkalinity (T.A.), are low or totally negligible on an annual basis. There are very few deposition episodes characterised by the presence of alkalinity, but they are often associated with high volumes. In fact, these episodes of intense rainfall are generally caused by air masses coming from North Africa, where they collect atmospheric calcareous dust (Guerzoni \& Chester 1996; Loye-Pilot et al. 1986).

If we also consider the major ion concentrations of the weekly episodes, the values measured at Graniga and at Domodossola are very similar (Fig. 2). In fact, a more extensive study of the chemical characteristics of atmospheric depositions on the Lake Maggiore watershed showed a regular decreasing gradient from South to North (Della Lucia et al. 1996; Marchetto et al. 1998), which also explains why there are no great differences between the two stations, located about $8 \mathrm{~km}$ apart; data from Graniga and Domodossola may therefore be used to study the atmospheric depositions affecting the watershed of the Paione lakes, located about $5 \mathrm{~km}$ from Graniga. The hydrochemistry of LPI and LPS is characterised by a very low ionic content, as is shown by the mean values of conductivity recorded in 1998 (9.6 and $12.4 \mu \mathrm{S} \mathrm{cm}^{-1}$ at $20{ }^{\circ} \mathrm{C}$ respectively). The respective values of total ionic concentrations are 150 and $214 \mu \mathrm{eq} \mathrm{l}^{-1}$. The main difference between the two lakes for the whole period 1984-1998 consists in the mean value of alkalinity, which fluctuated around zero during most of the period in LPS, whose catchment is formed almost exclusively of gneiss. In LPI alkalinity has been always above zero; in fact the catchment of this lake contains small amounts of more soluble minerals, such as micaschists. Moreover, LPI is characterised by a larger watershed area and lake surface ratio, which also influences the weathering processes in catchments. As a consequence, $\mathrm{pH}$ is higher in LPI, varying between 6.1 and 6.5; in LPS the pH range is between 5.5 and 6.3

Tab. 2. Precipitation amounts $(\mathrm{mm})$ and annual mean values of conductivity $\left(\mu \mathrm{S} \mathrm{cm}^{-1}\right)$ and of the concentration of major ions $\left(\mu\right.$ eq $\left.\mathrm{l}^{-1}\right)$ in atmospheric depositions at Graniga and Domodossola. Weighted averages on samples collected weekly.

\begin{tabular}{|c|c|c|c|c|c|c|c|c|c|c|c|c|c|c|}
\hline Sampling site & Year & Amount & $\mathrm{pH}$ & Cond. $20^{\circ} \mathrm{C}$ & $\mathrm{H}^{+}$ & $\mathrm{NH}_{4}^{+}$ & $\mathrm{Ca}^{++}$ & $\mathrm{Mg}^{++}$ & $\mathrm{Na}^{+}$ & $\mathrm{K}^{+}$ & Alc. & $\mathrm{SO}_{4}=$ & $\mathrm{NO}_{3}^{-}$ & $\mathrm{Cl}^{-}$ \\
\hline \multicolumn{15}{|l|}{ Graniga } \\
\hline & 1994 & 1717 & 4.77 & 17.5 & 17 & 29 & 31 & 5 & 5 & 2 & 13 & 44 & 30 & 6 \\
\hline & 1995 & 1562 & 4.67 & 15.4 & 21 & 29 & 17 & 3 & 4 & 2 & 0 & 37 & 29 & 5 \\
\hline & 1996 & 1853 & 4.69 & 13.8 & 20 & 26 & 9 & 2 & 4 & 1 & 1 & 28 & 25 & 4 \\
\hline & 1997 & 1610 & 4.67 & 15.3 & 21 & 34 & 11 & 2 & 5 & 2 & 0 & 32 & 29 & 6 \\
\hline & 1998 & 1251 & 4.61 & 19.2 & 25 & 43 & 14 & 2 & 6 & 3 & 4 & 37 & 40 & 5 \\
\hline Average & 1994-98 & 1599 & 4.68 & 16.1 & 21 & 32 & 17 & 3 & 5 & 2 & 4 & 35 & 30 & 5 \\
\hline \multicolumn{15}{|l|}{ Domodossola } \\
\hline & 1994 & 1709 & 4.69 & 16.1 & 20 & 25 & 26 & 4 & 5 & 2 & 9 & 37 & 26 & 5 \\
\hline & 1995 & 1323 & 4.65 & 15.1 & 22 & 30 & 15 & 3 & 4 & 2 & 0 & 36 & 27 & 5 \\
\hline & 1996 & 1459 & 4.63 & 15.1 & 23 & 23 & 10 & 2 & 4 & 1 & 0 & 29 & 25 & 4 \\
\hline & 1997 & 1168 & 4.71 & 14.2 & 19 & 29 & 10 & 2 & 6 & 1 & 0 & 29 & 27 & 5 \\
\hline & 1998 & 1178 & 4.69 & 15.4 & 20 & 30 & 10 & 2 & 4 & 2 & 1 & 28 & 31 & 4 \\
\hline Average & 1994-98 & 1367 & 4.67 & 15.3 & 21 & 27 & 15 & 3 & 5 & 2 & 2 & 32 & 27 & 5 \\
\hline
\end{tabular}



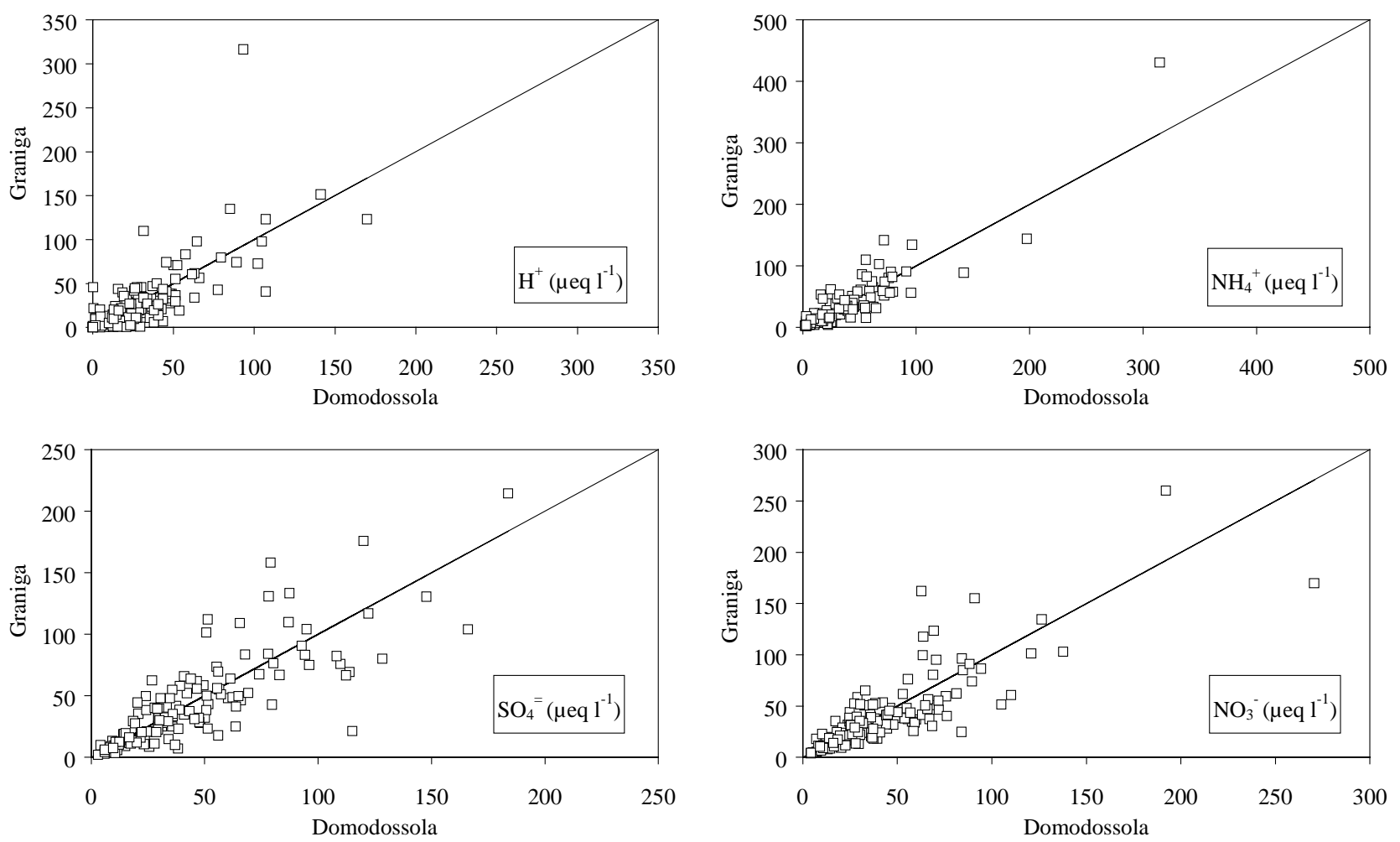

Fig. 2. Comparison between deposition concentrations recorded weekly at Graniga and Domodossola.

(annual mean values). Calcium, magnesium and sodium are the most important cations for both lakes, while sulphate and nitrate are the dominant anions. Alkalinity is quite important only in the case of LPI (26-38 $\left.\mu \mathrm{eq}^{-1}\right)$.

Figure 3 shows a comparison between the lake water and atmospheric deposition concentrations. Biological processes in the watersheds of the Paione lakes cause the almost total disappearance of ammonium, which is present in high concentrations in atmospheric depositions, but only in trace in lake water, owing to its consumption by vegetation and bacterial oxidation. Nitrate, on the other hand, has quite high concentrations in lake water, being less consumed because of the scarce vegetation present in the catchment. Sulphate is the most important anion in the lake waters, but also in rainwater. The weathering processes on soils and rocks cause the total neutralisation of atmospheric acidity, though only in LPI do the waters reach a significant supply of alkalinity. As a consequence of weathering, the lake waters also show a slight increase in calcium and magnesium content, compared to that found in atmospheric deposition.

Seasonal variations of ionic concentrations in lake water are at a minimum at the end of the snowmelt period, owing to the dilution effect of the melting ice, which has a low pollutant content. These changes are particularly evident for alkalinity and $\mathrm{pH}$ values, and help to create the scattered pluriannual trend (Fig. 4).
Inorganic nitrogen is often present with high concentrations in samples collected during snowmelt; the origin of this ion is mainly atmospheric input. In summer and autumn there is an increase in ionic concentrations, especially alkalinity and calcium, but also sulphate, magnesium, sodium and potassium, because of weathering processes and evaporation. Nitrate concentrations do not present marked seasonal variations in summer, because of the negligible consumption of this ion by phytoplankton for primary production.

As regards inorganic nitrogen, both concentrations and variations are almost the same for the two lakes. This fact is due to the meteorological origin of nitrate, unlike all the other ions, which derive more from the weathering processes.

Long term trends of lake water chemistry are shown in figure 4 . In the considered period there is a marked increase in $\mathrm{pH}$ values for both lakes, particularly evident in the case of LPS, which had $\mathrm{pH}$ values between 5.3 and 5.8 before 1992, while in the last three years they have been near or slightly above 6.0. In LPI, pH has been always above 6.0 , and in recent years it has been about 6.4. There is a similar upward trend for alkalinity, which emerges clearly for LPS, in spite of very marked seasonal fluctuations. In LPS alkalinity values have been close to zero for most of the period, but since 1995 they have always been positive, with an annual average between 8 and $11 \mu$ eq $1^{-1}$ in the period 1996-98. In LPI 


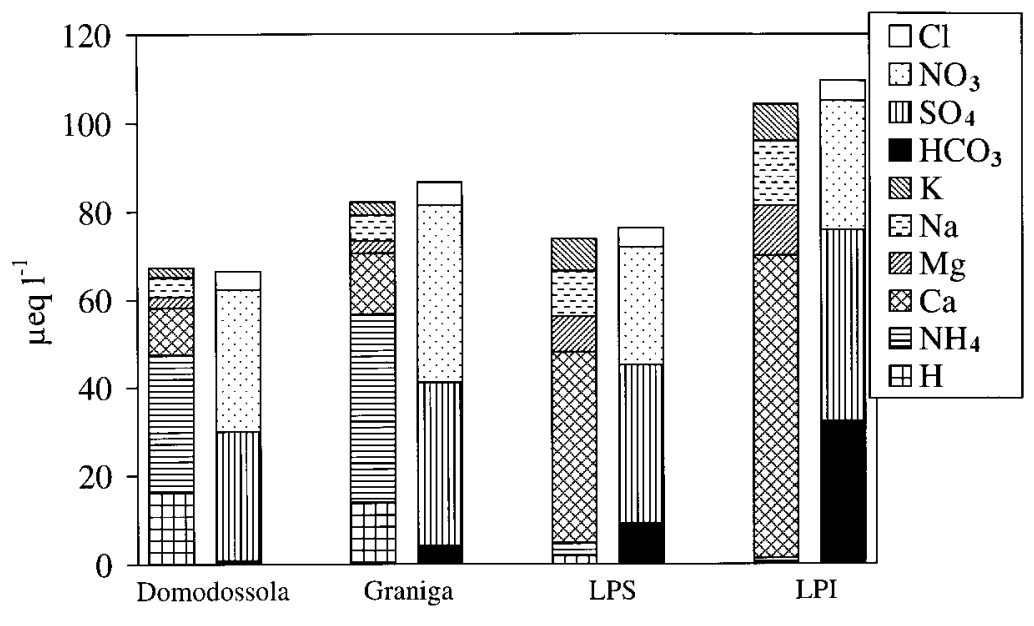

Fig. 3. Mean ionic concentrations in LPI and LPS and in atmospheric depositions collected at Graniga and Domodossola (annual means of 1998).
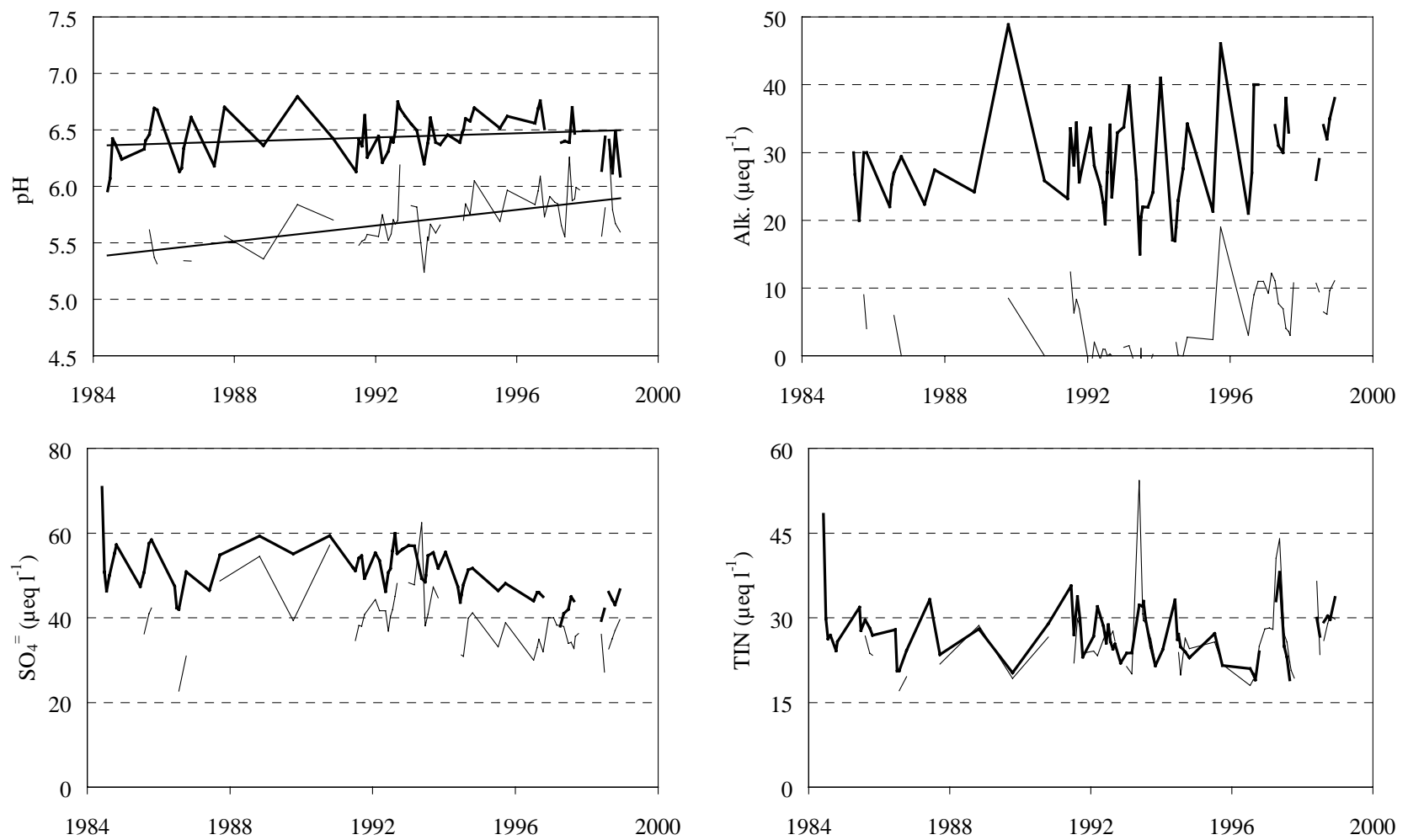

Fig. 4. Long term trends of some chemical variables in LPI (thick line) and LPS (thin line).

the mean annual values of alkalinity passed from 25-27 $\mu$ eq $1^{-1}$ for the period 1991-94 to $32-36 \mu$ eq $1^{-1}$ in 199698. Sulphate and nitrate do not present such clear variations or a significant trend, though sulphate concentrations appear to be decreasing slightly compared to the values of the period 1988-92. Values for LPI in 1991-93 and $1996-98$ are $52-54$ and $43-45 \mu \mathrm{eq}^{-1}$ respectively. For LPS the respective values are 38-46 and 34-36 $\mu$ eq $1^{-1}$. There is no significant trend in the case of inorganic nitrogen.

\section{DISCUSSION AND CONCLUSIONS}

Paleolimnological studies on sediments have revealed how the hydrochemistry of the Paione lakes has been influenced by acidic inputs coming from the atmosphere. Diatom remains, carbonaceous particle and pigment profiles in the sediments all indicate that the two lakes have undergone acidification since the fifties (Guilizzoni et al. 1996). 

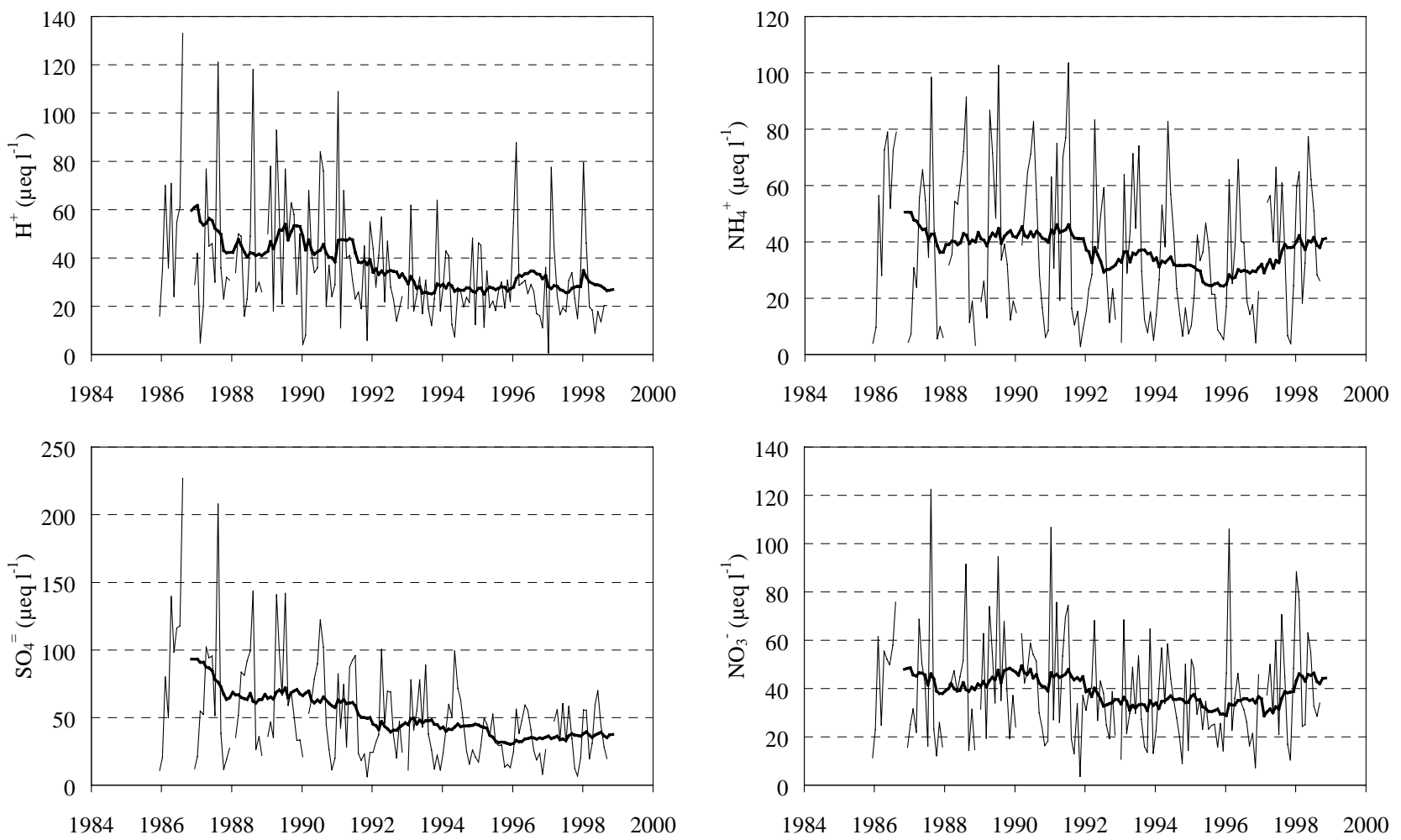

Fig. 5. Long term trends of some chemical variables in atmospheric depositions at Domodossola. Monthly values and twelve point running average.

Tab. 3. Precipitation amounts and fluxes of ions in atmospheric depositions at Domodossola during the first three years and the last three years of the study period.

\begin{tabular}{|c|c|c|c|c|c|c|c|}
\hline & Period & $\begin{array}{l}\text { Volume } \\
\text { (mm) }\end{array}$ & $\begin{array}{c}\mathrm{H}^{+} \\
\left(\text {meq m }{ }^{-2} \mathrm{y}^{-1}\right)\end{array}$ & $\begin{array}{c}\mathrm{NH}_{4}^{+} \\
(\text {meq m} \\
-2 \\
\left.y^{-1}\right)\end{array}$ & $\begin{array}{c}\mathrm{Ca}^{++} \\
\left(\mathrm{meq} \mathrm{m^{-2 }} \mathrm{y}^{-1}\right)\end{array}$ & $\begin{array}{c}\mathrm{SO}_{4}{ }^{=} \\
\left(\text {meq m}{ }^{-2} y^{-1}\right)\end{array}$ & $\begin{array}{c}\mathrm{NO}_{3}^{-} \\
\left(\text {meq m} \mathrm{y}^{-1}\right)\end{array}$ \\
\hline Average & $1986-88$ & 1606 & 60 & 56 & 36 & 89 & 50 \\
\hline Average & 1996-98 & 1268 & 28 & 34 & 13 & 37 & 35 \\
\hline
\end{tabular}

In this paper, changes in the lake water chemistry are compared with the long term trends observed for the chemical characteristics of atmospheric depositions collected at Domodossola. Trends of the four most important variables in atmospheric depositions are reported in figure 5 . We used a twelve point running average on the monthly concentrations, to smooth seasonal variations. There is a clear decrease in hydrogen ion over the study period: from $50-60 \mu \mathrm{eq}^{-1}$ in $1986-88$ to about $30 \mu \mathrm{eq} 1^{-1}$ in 1996-98. The respective increase for $\mathrm{pH}$ values is from 4.4 to 4.7 . There is also a marked decrease in sulphate concentrations, which are almost halved in the considered period. Nitrogen does not present such a sharp decrease, either as ammonium or nitrate; concentrations in the last three years of the study period are lower than those of the first three years by 10 and $23 \%$ respectively.

To estimate the effects of acidification on the lake water we also considered fluxes of the main ions from the atmosphere. These values, reported in table 3, confirm the halving of hydrogen ion and sulphate.

These decreases partly explain the appreciable increase of alkalinity in lake water, but we cannot exclude other processes. For example, we took into account the occurrence of some episodes of intense rainfall characterised by high values of alkalinity and the presence of calcareous particles which can dissolve and contribute subsequently to the total alkalinity content. We considered the number and total amount of the episodes with measurable alkalinity (detection limit $0.001 \mathrm{meq}^{-1}$ ), generally associated with $\mathrm{pH}$ values above 5.0 and calcium concentrations above the average. On a weekly basis, these episodes occurred from 1 to 3 times a year in the period 1986-1998, with no upward trend in the last years.

Another process which could favour an increase in water alkalinity is the rise in mean air temperature. This could encourage processes of rock weathering and the 
biological activity of vegetation in the watershed. This hypothesis has been advanced to account for the increase of alkalinity, calcium and silica in some high altitude lakes in the Austrian Alps (Sommaruga-Wögrath et al. 1997). While we cannot rule it out, there is no evidence for such a hypothesis in the case of the Paione lakes.

In conclusion, decreased deposition of acidity from atmosphere seems to account for most of the recovery of alkalinity in lake water. In contrast, the concentrations of nitrate, if compared with those of high altitude lakes in other areas of Europe (Wathne et al. 1997), still remain high, because of the still too high atmospheric load from the atmosphere. Studies continuing in the near future should focus on biota as well as on the chemical evolution; in fact, the changes in lake chemistry should shortly result in clear variations in biological populations, especially in LPS, whose waters are already beyond the critical level represented by the absence of alkalinity.

\section{ACKNOWLEDGMENTS}

$\mathrm{AL}: \mathrm{PE}$ project was funded by the European Commission Environment Programme (contracts STEPCT90-0079, EV5V-CT92-0205); MOLAR is funded as part of the European Commission 4th Framework, Environment and Climate Programme (contract ENV4CT95-0007). We thank the Comunità Montana Valle Ossola for their assistance in atmospheric deposition sampling.

\section{REFERENCES}

Boggero, A., A. Barbieri, M. Conedera, A. Marchetto, R. Mosello \& G.A. Tartari. 1993. Land cover as a factor influencing the chemistry of mountain lakes in the western Alps. Verh. int. Ver. Limnol., 25: 772-775.

Della Lucia, M., A. Marchetto, R. Mosello \& G.A. Tartari. 1996. Studies on a chemical gradient of atmospheric deposition from the Po Valley to the Alps. Wat. Air Soil Pollut., 87: 171-187.

Guerzoni, S. \& R. Chester (Eds). 1996. The impact of desert dust across the Mediterranean. Kluwer, Dordrecht: 389 pp.

Guilizzoni, P., A. Marchetto, A. Lami, N.G. Cameron, P.G. Appleby, N.L. Rose, Ø.A. Schnell, C.A. Belis, A. Giorgis \& L. Guzzi. 1996. The environmental history of a mountain lake (Lago Paione Superiore, Central Alps, Italy) for the last c. 100 years: a multidisciplinary, paleolimnological study. J. Paleolimnol., 15: 245-264.
Loye-Pilot, M.D., J.M. Martin, \& J. Morelli. 1986. Influence of Saharan dust on the rain acidity and atmospheric input to Mediterranean. Nature, 321: 427-428.

Marchetto, A., A. Boggero, M.C. Brizzio, R. Mosello \& A. Barbieri. 1998. Nitrogen content in atmospheric deposition and headwater lakes in the Lake Maggiore drainage basin. In: Tappeiner, U., F.V. Ruffini \& M. Fumai (Eds), $H y$ drology, Water Resources and Ecology of Mountain Areas.(Proc. of the HeadWater Conference, Meran, Italy, April 1998): 218-221.

Marchetto, A., R. Mosello, R. Psenner, G. Bendetta, A. Boggero, D. Tait \& G.A. Tartari. 1995. Factors affecting water chemistry of alpine lakes. Aquat. Sci., 55: 81-89.

Mosello, R. \& G. Tartari. 1982. Chemistry of the precipitation in the Lake Maggiore watershed (N. Italy). Mem. Ist. ital. Idrobiol., 40: 163-180.

Mosello, R. \& A. Marchetto. 1995. Chemistry of atmospheric deposition in Italy: results from a five year study. Ambio, 25: $21-25$

Mosello, R., A. Barbieri, G. Bendetta, A. Boggero, A. Marchetto, R. Psenner, D. Tait \& G.A. Tartari. 1993b. Quantification of the susceptibility of alpine lakes to acidification. Mem. Ist ital. Idrobiol., 52: 355-386.

Mosello, R., P. Guilizzoni, A. Lami, M. Manca, A.M. Nocentini, A. Pugnetti, A. Boggero, A. Marchetto, G.A. Tartari, R. Bettinetti, M. Bonardi \& P. Cammarano. 1992. Limnological studies on two acid sensitive lakes in the South Western Alps (Lakes Paione Superiore and Paione Inferiore, Italy). Mem. Ist. ital. Idrobiol., 51: 127-146.

Patrick, S., R.W. Battarbee, B. Wathne \& R. Psenner. 1998. Measuring and modelling the dynamic response of remote mountain lake ecosystems to environmental change: an introduction to the MOLAR project. Hydrology, Water Resources and Ecology in Headwater (Proc. of the Headwater Conference, Meran, Italy, April 1998), IAHS Publ. 248: 403-410.

Sommaruga-Wögrath, S., K.A. Koinig, R. Schmidt, R. Sommaruga, R. Tessadri \& R. Psenner. 1997. Temperature effects on the acidity of remote alpine lakes. Nature, 387 : 64-67.

Tartari, G.A. \& R. Mosello. 1997. Metodologie analitiche e controlli di qualità nel laboratorio chimico dell'Istituto Italiano di Idrobiologia. Documenta Ist. ital. Idrobiol., 60: $160 \mathrm{pp}$.

Tonolli, V. 1947. Gli alti laghi della Val Bognanco. Parte I. Mem. Ist. ital. Idrobiol., 3: 185-269.

Tonolli, V. 1949. Gli alti laghi della Val Bognanco. Parte II. Mem. Ist. ital. Idrobiol., 5: 39-93.

Wathne B.M., S. Patrick, \& N.G Cameron. 1997. AL:PE Acidification of mountain lakes: palaeolimnology and ecology. Part 2 - Remote mountain lakes as indicators of air pollution and climate change. NIVA Report 3538-97, Oslo.

Wathne B.M., S.T. Patrick, D. Monteith \& H. Barth. 1995. AL:PE - Acidification of mountain lakes: palaeolimnology and ecology. AL:PE 1 report for the period April 1991April 1993. European Commission, Ecosystem Research Report 9. Luxembourg. 